\title{
The Influence of Instructional Models and Learning Styles on the Ability to Read to Understand
}

\author{
Maimunah ${ }^{1, *}$, Nurdin Ibrahim², Suyitno Muslim², Jarudin $^{3}$ \\ ${ }^{1}$ Department of Education Technology, State University of Jakarta, Indonesia \\ ${ }^{2}$ Universitas Negeri Jakarta, Indonesia \\ ${ }^{3}$ Department of Information Technology, STMIK Bina Sarana Global, Indonesia
}

Received October 24, 2019; Revised January 21, 2020; Accepted February 25, 2020

Copyright $\bigcirc 2020$ by authors, all rights reserved. Authors agree that this article remains permanently open access under the terms of the Creative Commons Attribution License 4.0 International License

\begin{abstract}
The purpose of this study was to determine the effect of Instructional models and learning styles on learning outcomes of reading skills. Reading is part of the educational process of developing self-potential so that it can think rationally towards academic achievement. Researchers are of the view that teachers should introduce a variety of reading strategies that are relevant to the needs of students. This study aims to obtain a picture of the influence of think, talk, write learning models and picture to picture learning models (external factors) as well as visual and auditory learning styles (internal factors) on the ability of reading to understand the contents of the Baitussalam Integrated Islamic Qurrata'ain Elementary School in Bogor. Experimental research methods with quantitative research approaches are conducted to test the effect of a variable on other variables with the two-way Anava test. 104 respondents were divided into four classes, each class consisting of 26 students. Each class is distinguished by instructional models and learning styles namely instructional models think, talk, write and picture to picture while the learning styles are visual and auditory. The hypothesis there is a positive influence of instructional models on reading skills, and there is a positive influence on learning styles and reading skills. The results of this research depicted that the picture of the instructional model and visual learning style significantly influence reading skills.
\end{abstract}

Keywords Instructional Model, Learning Style, Reading Ability

\section{Introduction}

Reading is a valuable skill that can be used throughout life. Good reading is demonstrated by one's ability to complete reading assignments easily and quickly accompanied by understanding to get better grades and learn quickly. This has an impact on the ability to finish school and live an easier life (Dietz, Knollman-Porter, Hux, Toth, \& Brown, 2014). From the description, it is explained that reading is a valuable/important skill as part of learning. The importance of learning to read is outlined in Law No. 19 of 2005 Concerning National Education Standards article 6 paragraph 5 which reads SD / MI / SDLB / Package A curriculum and syllabus or other equivalent forms emphasizing the importance of reading and writing skills, numeracy skills, and communication skills (UU, 2005).

Besides being important, reading is part of the educational process, as stated in Permendikbud No 67 of 2013 concerning the Basic Framework and Curriculum Structure which states: The educational process is a process that allows students to develop their potential into rational thinking skills and academic brilliance by giving meaning to what is seen, heard, read, learned from cultural heritage based on the meaning determined by the cultural lens and following the level of psychological maturity and physical maturity of students (Permendikbud, 2013).

The statement explained that reading is part of the educational process of developing self-potential so that it can think rationally and academic achievement. Reading with question is getting the meaning of what he reads. A good reader tries to get meaning in the form of understanding of what he reads. Reading comprehension is a reading activity that is directed to get an understanding of the reading content.

According to Khasanah and Cahyani (2016) "reading comprehension or reading for understanding is one form of reading activities with the main objective to understand the contents of the message contained in the reading. Reading puts more emphasis on mastering the content of reading, not on beautiful, fast or slow reading' (Khasanah \& 
Cahyani, 2016).

Jusoh and Abidin (2012) argue that "reading learning can be interpreted as a series of activities carried out by students to achieve reading skills." Furthermore, it was also explained that reading learning is not solely done so that students can read, but also a process that involves all activities mentally and thinking students in understanding, criticizing, and reproducing a written discourse. According to him, the activities that can be done by students are very diverse depending on the reading strategies applied by the teacher in learning(Jusoh \& Abidin, 2012).

The two descriptions above provide an overview of learning to understand. The activity also applies to learn other language skills and all subjects. Boema, Mo and Jolles (2017) state that developing reading comprehension skills is one of the responsibilities of teachers teaching reading in elementary schools. The development of reading comprehension ability is directed at analyzing and understanding the contents of the text and providing responses that are appropriate to the contents of the text (Boerma, Mol, \& Jolles, 2017).

Regarding the responsibility of teachers in learning to read, Jusoh and Abidin, (2012) states "teachers should introduce a variety of reading strategies that are relevant to the needs of students' (Jusoh \& Abidin, 2012). Furthermore, he also revealed that the introduction of reading strategies should be practiced by teachers and students when learning takes place.

This problem needs to be immediately followed up with efforts to improve reading skills as one of the basic skills that must be possessed by a student. This can be through reading learning innovations in Indonesian subjects, especially in elementary schools. One effort that can be made by elementary school educators is the application of various models of reading learning, especially reading comprehension. For this reason, researchers need to conduct research under the title of research. The influence of learning models and learning styles on the ability to read comprehends the reading content.

This study aims to obtain a picture of the influence of think, talk, write learning models and picture to picture learning models (external factors) as well as visual and auditory learning styles (internal factors) on the ability to read to understand the contents of the Baitussalam Integrated Islamic Qurrata'ain Elementary School in Bogor.

\section{Literature Review}

The ability to read is a reading activity that is done to understand the contents of the reading. The main purpose of reading comprehension activities is to understand the contents of the reading. Specifically, at the elementary school level, comprehension reading activities include (a) reading with good comprehension, (b) reading without lip or head movements or pointing with fingers, (c) enjoying reading material in the heart(Lustyantie, 2015). Thus, the understanding referred to in this activity is the reading of literal texts literally and partially assisted with interpretive understanding.

Reading comprehension is a complex process, including physical and mental activities. Reading comprehension at the elementary school level, especially in class III students, is an inseparable part of general reading principles, as follows: (1) reading is not only about recognizing and sounding letters, but reading activities go beyond recognition of letters and sounds. (2) reading and mastering language occur simultaneously. A person cannot be said to have reading skills if he does not master the language. (4) reading and thinking occur simultaneously. People cannot read without using their thoughts and feelings. (5) reading means understanding. This means that reading activities lead to understanding (Pardo, 2004).

Based on research conducted by the Progress in International Reading Literacy Study (PIRLS), which is an international study in the field of reading in children throughout the world sponsored by the International Association for the Evaluation of Achievement shows that the average reading ability of Indonesian children ranks fourth from under 45 countries in the world (Word-Bank, 2017). This means that the reading ability of Indonesian children is still relatively low.

The Ministry of National Education noted that in 2008 10.1 million people in Indonesia were illiterate between the ages of 15-44. This illiteracy also influenced the low reading ability of students in Indonesia. Meanwhile, the International Educational Achievement recorded the lowest reading ability of Indonesian students in the ASEAN region. Indonesia was ranked 38th out of 39 countries. That caused the United Nations Development Program (UNDP) to place Indonesia in the lowest order in terms of human resource development (Undp, 2012). Based on the above studies, it shows that the reading ability of students in Indonesia is still relatively low.

Hamid and Yunus (2016) in his research found that the average reading speed of junior high school students in Watunohu, the improvement of the average students' value which is shown in preliminary study the students only reached average 43.56 or only $32 \%$ or 6 from 26 students got the score greater than or equal to 72 . Second, the average of the students' value was 58.74 in the first cycle where only $44 \%$ or 8 from 26 students got the score greater than or equal to 72(Hamid \& Yunus, 2016).

Mullis et al (2012) Progress in International Reading Literacy Study (PIRLS) conducted a study of reading skills. The study report reveals that the reading ability of grade IV elementary / MI students in Indonesia is relatively low. Only 5\% of Indonesian students studied showed the ability to read to high and advanced levels, while more than $30 \%$ were at very low levels, almost $40 \%$ were only low and even only $25 \%$ of students reached intermediate levels. The default is that the ability to read is not just being able to 
read, but furthermore, that is reading by understanding what is read, what is the meaning of the reading and what are the implications (Mullis, Martin, Foy, \& Drucker, 2012).

Good learning is needed to understand good concepts as well. The importance of understanding concepts in the learning process greatly influences attitudes, decisions, and ways of solving problems. Understanding what is meant is understanding students of facts that are interrelated with their ability to use that knowledge in new situations(Richardson, 2016).

Educators play a role in producing quality students, such as providing learning services that are appropriate to the situation and conditions, as well as being fun for students. One form of the service is in the form of how to do the learning strategies used, facilities and infrastructure used, learning models, and learning methods used in the learning process (King, South, \& Stevens, 2017).

According to Richardson (2016), the problem in learning today is finding the best way to convey a variety of concepts taught by educators, so students can remember the concept longer and apply it in real life. Learning models that are appropriate to students' problems and characteristics(Richardson, 2016). In the problem-based learning model, learning is controlled by problems so that students are accustomed to starting by solving problems and then proposed to gain new knowledge (Maysara, 2016). This will make students not only learn the basic concepts in memorization but also understand individually, so learning or reading does not have to be memorized but they will try to find and understand a concept based on the learning model so that students can understand the meaningful reading. Therefore, it can be said that a learning model will facilitate students in finding an understanding of a material that is read.

The use of approaches, methods, and techniques of reading that are not appropriate is one of the determinants of the lack of maximum achievement of the learning goals of reading in schools. Realizing the importance of a learning model to develop students' reading skills, it is necessary to have reading learning that more actively involves students in the learning process itself. Therefore, it is necessary to use creative and innovative ways that can stimulate students' motivation and students' interest in reading.

In addition to the learning model, other factors that influence the success of a learning process are students themselves. According to Drachsler and Kirscjner (2011), students themselves have characteristics that can influence learning activities, among others, background knowledge, level of knowledge, learning motivation, learning style, initial ability, socio-economic environment, intelligence, and others(Drachsler \& Kirscjner, 2011). Learning style is a way of learning for students who are preferred in doing the activities of thinking, processing, and understanding information or material that is read. Each student has a learning style that is not the same as the others. Children will learn according to their learning styles, and each learning style affects their learning outcomes. According to Fan and Xiao (2015), a child encounters a learning environment that is incompatible with his learning style, then the child will reject the learning environment. Therefore, it can be said that learning styles affect the learning outcomes of students(Fan \& Xiao, 2015).

According to Gokalp (2003), students who learn in their learning styles while taking tests will achieve significantly higher grades than if they learn in ways that are not in line with their learning styles(Gokalp, 2013). This opinion is reinforced by the results of research conducted which concluded that learning styles have a positive effect on learning achievement(Cimermanová, 2018).

\section{Methodology/Materials}

The method used in this study is an experimental method with a quantitative approach that aims to find the influence between variables. Furthermore, to determine the effect of one variable on another variable, the technique used is the variant analysis technique. 104 respondents are divided into four classes, each class consisting of 26 students.

The variables tested and analyzed are 1). Learning, think, talk, write (A1) learning strategies. 2). The picture to picture strategy (A2), 3). Visual learning style (B1) 4) auditory learning style (B2) and the ability to understand reading content $(\mathrm{Y})$. Research data collection for the variable ability to understand the contents of reading using questionnaires, for the variable learning strategies and learning styles using tests given to respondents in the form of questions with multiple choice answers to four-choice of answers. As for the variable ability to understand the content of the reading with the questionnaire using a Likert scale assessment presents five answer choices, namely: Strongly Agree (SS), Agree (S), Disagree (KS) and Disagree (TS) Strongly Disagree (STS).

\section{Results and Findings}

The first class is given a think talk write (TTW) strategy and the second class is given a picture to picture (PP) strategy. After being given treatment, each sample class is given an evaluation of learning in the form of learning outcomes tests. The test is used as an instrument to obtain student learning outcomes data. The following graphs the data of learning outcomes reading skills.

Figure 1 shows the lowest value for TTW class 65 while the highest value is 89 . Based on the calculation of the data description of learning outcomes obtained an average value for the TTW class is 75.65 . It means that the average learning outcomes of the TTW class are quite high because it has reached the KKM of the school for reading ability, which is 75 . 


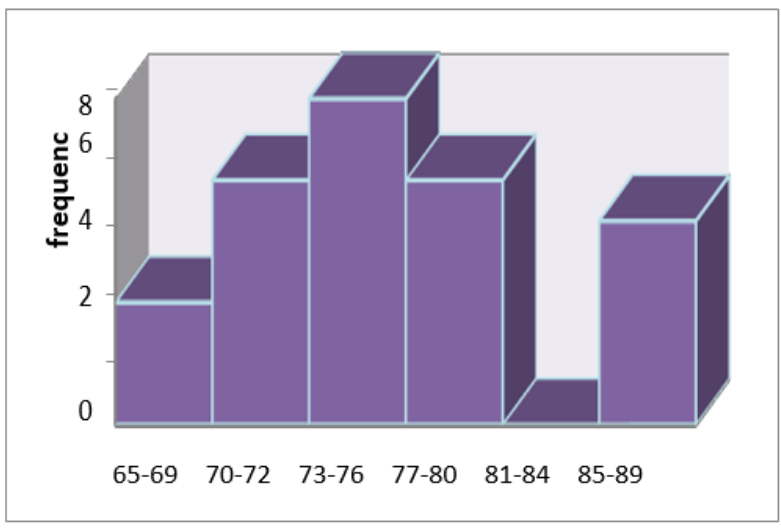

Figure 1. learning outcomes reading skills Class TTW

Figure 2 shows the lowest value for PP class 55. While the highest value is 84 . Based on the calculation of the data description of learning outcomes obtained the average value for PP class is 69.65. This means the average PP learning outcomes are still low because the school KKM has not reached the reading ability that is 75 .

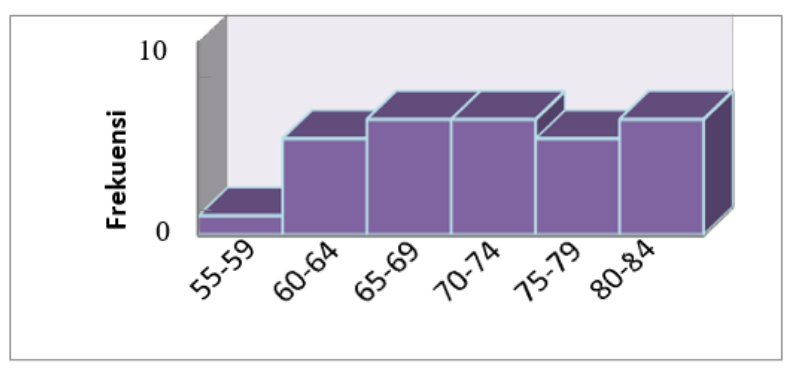

Figure 2. learning outcomes reading skills Class PP

To determine students' learning styles, this study used a learning style questionnaire. The learning style questionnaire contains 18 statements with two alternative answers. The following table 1 data is the result of grouping student learning styles.

Table 1. Description learning style student

\begin{tabular}{|c|c|c|c|}
\hline $\begin{array}{c}\text { The number of } \\
\text { students }\end{array}$ & $\begin{array}{c}\text { Learning } \\
\text { Style }\end{array}$ & & Total \\
\hline & Visual & Auditory & \\
\hline $\begin{array}{c}\text { Class Think Talk } \\
\text { Write }\end{array}$ & 17 & 12 & 29 \\
\hline Picture to Picture & 16 & 12 & 28 \\
\hline Total & $\underline{33}$ & 24 & $\underline{57}$ \\
\hline
\end{tabular}

Table 1. shows that the TTW class has a visual learning style. This means that the TTW and PP classes have different learning styles. Before testing the hypothesis first, the learning outcome data is tested for normality and homogeneity as a prerequisite test. Test for normality uses the Lilliefors method with a significance level of 5\%. After the calculation is obtained $\mathrm{lh}<0.05$ it can be interpreted that $\mathrm{H} 0$ is accepted. This means that for each sample group both the learning strategy group and the learning styles come from populations that are normally distributed. After the formality requirements are met, the homogeneity prerequisite test is then performed. The homogeneity test uses the Bartlet test with a significance level of 5\%. Based on the homogeneity test results $\mathrm{h}<0.05$ which means that $\mathrm{H}_{0}$ is accepted.

Therefore, it can be concluded that the two sample groups have the same or homogeneous variance.

In this study, the hypothesis testing uses a two-way analysis of variance test with cells equal to a significant level of 5\%. Table 2 shows the results of two-way variance analysis calculations with unequal cells.

Table 2. Hypothesis Test Results

\begin{tabular}{ccccccc}
\hline Source & $\mathrm{JK}$ & $\mathrm{dk}$ & $\mathrm{RK}$ & $\mathrm{Fh}$ & $\mathrm{F} \alpha$ & Decision \\
\hline Strategy (A) & 172,642 & 1 & 172,642 & 4,288 & 4,03 & H0 rejected \\
\hline Learning Style (B) & 540,943 & 2 & 270,472 & 6,717 & 3,18 & H0 rejected \\
\hline Interaction (AB) & 58,31 & 2 & 29,155 & 0,724 & 3,18 & H0 received \\
\hline Galat & 2053,472 & 51 & 40,264 & - & - & \\
\hline Total & 2825,368 & 56 & & & & \\
\hline
\end{tabular}


1) Based on the analysis of variance results obtained for $\mathrm{Fh}>\mathrm{F} \alpha$ which means that $\mathrm{H}_{0}$ is rejected, it can be concluded that the learning strategy affects reading ability. By looking at the marginal average, the marginal average of TTW class students is 75.714 greater than the marginal average of PP class students which is 69.655 . Based on these results it can be concluded that the TTW strategy provides better reading ability results than the PP strategy.

2) Due to the TTW learning strategy learning activities take place more actively and effectively. Munawaroh (2012) also explained that learning with TTW was able to increase students' motivation to be active in learning activities (Munawaroh, 2012). The same thing was also explained by Cawi et. al (2014) that TTW made the learning experience more interesting and meaningful for students. In other words, this strategy can increase the activeness of students in taking lessons in class(Cawi et al., 2014).

Besides, making work on the TTW strategy makes students more enthusiastic in participating in learning, plus the provision of rewards for groups that succeed in getting the best grades makes students more motivated in completing work. Whereas in class with PP strategy, learning activities do not run smoothly. Not all students actively participate in learning activities. There are still many students who are not focused on participating in learning activities. Students who are not ready to learn are just waiting for a groupmate to complete a given task. Rahman and Maarif (2014) explain this strategy invites students to learn by discovering and investigating their knowledge. Therefore, for students who do not have the readiness of mind to learn will have difficulty in participating in learning activities with this strategy. Based on the description above it can be concluded that learning by applying the Think Talk Write strategy is more active and effective in achieving learning objectives so that it produces better reading skills(Rahman \& Maarif, 2014).

\section{Conclusions}

Based on the results of the analysis of variance tests, there is a significant effect of Think Talk Write learning strategies on the ability to read to understand the contents of reading, it can be concluded that the think talk writes strategy gives better results when compared to the picture to picture strategy.

There is an influence of learning styles on learning outcomes of students' reading skills. Based on the results of the post-anava further test, it was concluded that the learning outcomes shown by students with visual style were as good as the learning outcomes of students reading skills with auditory learning styles, as well as students with visual and auditory learning styles showed better learning outcomes compared to student learning outcomes with learning styles auditory. (3) There is no interaction between learning strategies with student learning styles on learning outcomes of reading skills. The impact is to increase the ability to understand the contents of the reading divide for elementary school students.

\section{REFERENCES}

[1] Boerma, I. E., Mol, S. E., \& Jolles, J. (2017). The Role of Home Literacy Environment, Mentalizing, Expressive Verbal Ability, and Print Exposure in Third and Fourth Graders' Reading Comprehension. Scientific Studies of Reading, 21(3), 179-193. https://doi.org/10.1080/1088843 8.2016.1277727

[2] Cawi, I. W., Marhaeni, A. A. I. N., Dantes, G. R., Studi, P., Pendidikan, E., \& Pascasarjana, P. (2014). ON LAYOUT LEARNING OUTCOMES WITH SPATIAL INTELLIGENCE AND MATHEMATICAL LOGIC INTELLIGENCE. E-Journal Program Pascasarjana Universitas Pendidikan Ganesha, 4(2), 1-11.

[3] Cimermanová, I. (2018). The Effect of Learning Styles on Academic Achievement in Different Forms of Teaching. International Journal of Instruction, 11(3), 219-232. https://doi.org/https://doi.org/10.12973/iji.2018.11316a

[4] Dietz, A., Knollman-Porter, K., Hux, K., Toth, K., \& Brown, B. (2014). Supported reading comprehension for people with aphasia: Visual and linguistic supports. Journal of Medical Speech-Language Pathology, 21(4), 319-331.

[5] Drachsler, H., \& Kirscjner, P. A. (2011). Learner Characteristics. Centre for Learning Sciences and Technologies, (January), 1-6. https://doi.org/10.1007/978$1-4419-1428-6$

[6] Fan, K., \& Xiao, P. (2015). The Effects of Learning Styles and Meaningful Learning on the Learning Achievement of Gamification Health Education Curriculum. Eurasia Journal of Mathematics, Science \& Technology Education, 11(59), 1211-1229. https://doi.org/10.12973/eurasia.2015. $1413 \mathrm{a}$

[7] Gokalp, M. (2013). The Effect of Students ' Learning Styles on Their Academic Success. Scientific Research, 4(10), 627-632.

https://doi.org/http://dx.doi.org/10.4236/ce.2013.410090

[8] Hamid, L. O. M. I. B., \& Yunus, M. (2016). Developing the Students 'Ability in Reading through Speed Reading Technique. Journal of English Education, 1(1), 42-50. Retrieved from URL:http://usnsj.com/index.php/JEE/articl e/view/JEE007

[9] Jusoh, R., \& Abidin, Z. Z. (2012). The Teaching-Research Nexus: A Study on the Students' Awareness, Experiences, and Perceptions of Research. Procedia - Social and Behavioral Sciences, 38(December 2012), 141-148. https://doi.org/10.1016/j.sbspro.2012.03.334

[10] Khasanah, A., \& Cahyani, I. (2016). Improved Reading Comprehension Ability with Question-Answer Relationships (QAR) Strategies for Grade V Students in Primary Schools. Pedagogik Pendidikan Dasar, 4(Juli), 
161-175.

[11] King, J., South, J., \& Stevens, K. (2017). Reimagining the Role of Technology in Education: Education Technology, (January). Retrieved from http://tech.ed.gov.

[12] Lustyantie, N. (2015). The Ability of Reading Comprehension of French Literary Texts with Contextual Approach. European Journal of Social Sciences, 47(2), 225-236. Retrieved from http://www.europeanjournalofso cialsciences.com

[13] Maysara. (2016). THE EFFECTIVENESS OF PROBLEMBASED LEARNING ( PBL ) MODEL ON STUDENTS ' LEARNING OUTCOMES AT CLASS XI IPA 2 OF SENIOR HIGH SCHOOL 5 SOUTH KONAWE ON THE SUBJECT OF COLLOID SYSTEM. International Journal of Education and Research, 4(7), 493-504. Retrieved from www.ijern.com

[14] Mullis, I. V. S., Martin, M. O., Foy, P., \& Drucker, K. T. (2012). PIRLS 2011 International Results in Reading. USA: TIMSS \& PIRLS International Study Center.

[15] Munawaroh, R. (2012). Application of Project-Based Learning Models to Build the Four Pillars of Instructional. Unnes Physics Education Journal, 1(1), 33-37.

[16] Pardo, L. S. (2004). What Every Teacher Needs to Know About Comprehension. The Reading Teacher, 58(3), 272280. https://doi.org/10.1598/rt.58.3.5

[17] Permendikbud. (2013). REGULATION OF THE MINISTER OF EDUCATION AND CULTURE NUMBER 67 OF 2013 CONCERNING BASIC FRAMEWORK AND STRUCTURES OF BASIC SCHOOL / MADRASAH IBTIDAIYAH. Jakarta: Dinas Pendidikan Nasional.

[18] Rahman, R., \& Maarif, S. (2014). The effect of using discovery methods on mathematical analogy abilities. Jurnal Ilmiah Program Studi Matematika STKIP Siliwangi Bandung, 3(1), 33-58.

[19] Richardson, V. (2016). The role of attitudes and beliefs in learning to teach. In International Journal Sikula (Ed.), Handbook of research on teacher education (2nd ed., pp. 102-119). New York.

[20] Undp, I. (2012). Annual Report UNDP Indonesia. Retrieved from www.id.undp.org

[21] UU. (2005). GOVERNMENT REGULATION OF THE REPUBLIC OF INDONESIA NUMBER 19 OF 2005 CONCERNING STANDARDS OF NATIONAL EDUCATION. GOVERNMENT REGULATION OF THE REPUBLIC OF INDONESIA, Vol. 19, pp. 1-95. https://doi.org/10.1016/j.hbrcj.2014.06.002

[22] Word-Bank. (2017). Learning to realize education's promise. World Development Report 2018: Learning to Realize Education's Promise, pp. 1-35. https://doi.org/10.1596/97 8-1-4648-1096-1_ov 